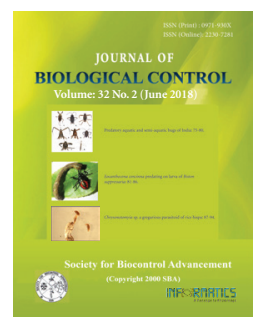

\title{
Antifungal activity of Bacillus subtilis subsp. spizizenii (MM19) for the management of Alternaria leaf blight of marigold
}

\author{
R. PRIYANKA ${ }^{1 *}$, S. NAKKEERAN ${ }^{1}$, I. ARUMUKA PRAVIN ${ }^{1}$, A. S. KRISHNA MOORTHY ${ }^{1}$ and \\ U. SIVAKUMAR ${ }^{2}$ \\ ${ }^{1}$ Department of Plant Pathology, Tamil Nadu Agricultural University, Coimbatore - 641003, Tamil Nadu, India \\ ${ }^{2}$ Department of Agricultural Microbiology, Tamil Nadu Agricultural University, Coimbatore 641003, Tamil Nadu, India \\ ${ }^{*}$ Corresponding author E-mail: vinumarajendran@gmail.com
}

\begin{abstract}
Biological control with bioagents is a cost effective alternate method for the management of crop diseases. The antagonistic bacterial strains were explored for the management of leaf blight of marigold which is caused by Alternaria alternata. The present study clearly proved that the mycelial growth of A. alternata was inhibited up to $83 \%$ by Bacillus subtilis subsp. spizizenii (MM19) in vitro. GC/MS analysis of partially purified extracts of B. subtilis subsp. spizizenii (MM19) revealed the presence of antifungal Phthalic acid esters which might be responsible for the inhibition of the pathogen. Foliar application of B. subtilis subsp. spizizenii (MM19) under field conditions suppressed leaf blight by $77 \%$. This study highlighted the potential of $B$. subtilis subsp. spizizenii (MM19) for the management of Alternaria leaf blight.
\end{abstract}

KEY WORDS: Alternaria, Bacillus subtilis subsp. spizizenii, GCMS, PCR

(Article chronicle: Received: 15-03-2018; Revised: 22-05-2018; Accepted: 30-05-2018)

\section{INTRODUCTION}

Marigold is a seasonal flower and can be grown round the year. Marigold flowers gained popularity amongst gardeners and dealers on its easy cultivation and wide adaptability. Marigold as a cut flower and loose flower is extensively used in the social and religious function for internal decoration and garlands. The leaves and flowers are known to possess high phenolic and antioxidant properties can be exploited in pharmaceutical industry (Khalil et al., 2007). Marigold is used as the trap crop in the borders to attract the insects attacking the main crop (Kolambkar et al., 2013). Marigold is infected with fungal, viral and bacterial diseases. Among the diseases, inflorescence blight caused by Alternaria zinnia Ellis is the most common disease in marigold, the infection causes considerable damage to the ornamental crops (Karlatti and Hiremath, 1989). In 2014, Aktar and Shamsi reported the leaf, bud and flower blight of $T a$ getes erecta and T. patula. was caused by A. alternata. In 1966, Shome and Mustafee reported that the leaf spot and flower blight was a serious disease of marigold in northern Madhya Pradesh. The leaf spot in marigold initially appear as necrotic spot, latter it progresses as leaf blight and completely coalesce leads to drying of entire leaf. This disease emerged as major constraint in exploitation of high yielding marigold varieties in the country. Excessive use of fungi- cide leads to the resistance in pathogen and also it affects the human and environment directly or indirectly resulting in ecological imbalance (Waghmare et al., 2011). Exploitation of biocontrol agents for the management of this disease is an alternative. Effective inhibition of mycelial growth of A. solani causing leaf blight of tomato by Bacillus subtilis has been reported (Babu et al., 2000; Mishra et al., 2013). It was also found that Bacillus have strong antifungal activity both in vitro as well as in vivo conditions against $A$. solani isolated from tomato (Zhao et al., 2008). Bacillus species are capable of producing a wide variety of secondary metabolites that are diverse in structure and function. The production of antimicrobial metabolites determines their ability to control plant diseases (Silo-suh et al., 1994). Hence, the present investigation was carried out to find alternate methods for controlling the leaf blight of marigold by evaluating the bioefficacy of bacterial bioagents for the management of marigold leaf blight.

\section{MATERIALS AND METHODS}

\section{Survey and collection of samples}

Survey for the occurrence of leaf blight in marigold was conducted in Krishnagiri, Tharmapuri, Madurai and Sakthiyamangalam district of Tamil Nadu during 20152016. The fields were having marigold hybrids like US45, 
Benz tall, Gold colour, Yellow. Plants showing characteristic blighting symptom were collected. The per cent disease index for each hybrids/variety was observed and they were classified using the disease score as described by Manojkumar et al., (2013).

$$
\text { Percent disease index }=\frac{\begin{array}{c}
\text { Sum of individual rating } \\
\text { of infected leaves }
\end{array}}{\begin{array}{l}
\text { Number of leaves observed } \\
\times \text { Maximum disease score }
\end{array}} \times 100
$$

\section{Isolation and identification of pathogen}

Small segments of diseased tissue along with some healthy portion $\left(5 \times 5 \mathrm{~mm}^{2}\right)$ from the infected leaf samples were cut by sterile razor and surface sterilized in $0.5 \%$ sodium hypochlorite $(\mathrm{NaOCl})$ for 1 minute. Surface sterilized plant tissue were rinsed twice by sterilized distilled water for removing the traces of Sodium hypochlorite, dried on filter paper and plated on Petri plates containing Potato Dextrose Agar medium (PDA) amended with 100 $\mu$ g/ $\mathrm{ml}$ of streptomycin sulphate. The plates were incubated at room temperature for 48 to $72 \mathrm{hrs}$. Later the plates were observed for growth of fungus. The fungal pathogen was purified by single spore isolation method on plain agar medium (Tutte, 1969). Morphological characters of all the strains were studied on PDA as described by Simmons (2007).

\section{Molecular characterization}

The fungus was cultured on potato dextrose broth at room temperature for two weeks. Then the mycelium was collected, dried and powdered by freezing in liquid nitrogen. The genomic DNA was extracted by Cetyl Trimethyl Ammonium Bromide (CTAB) method as described by Chakraborty et al. (2010). The extracted genomic DNA was subjected to PCR with ITS 1 (5'-TCCGTAGGTGAACCTGCGG-3') and ITS 4 (5'-TCCTCCGCTTATTGATATGC-3') primer pair (White et al., 1990). The PCR product was analyzed on $1.2 \%$ agarose gel, stained with ethidium bromide and viewed under transilluminator. The amplified fragments were sequenced and confirmed using NCBI database.

\section{Pathogenicity}

Spore suspension was prepared with $10^{5}$ conidia per $\mathrm{ml}$. Tween 20 was added to the suspension at a final concentration of $0.05 \%$. The spore suspension containing 10000 conidia/ml in phosphate buffer $(\mathrm{pH} 7)$ was sprayed over healthy plants using atomiser. Inoculated plants were covered in polythene bags and incubated at room temperature for one week. Simultaneously, a healthy control was also maintained. The experiment was replicated thrice with three plants per replication. The fungus was reisolated from the plants expressing the typical symptoms to confirm Koch's postulates.

\section{In vitro screening of antagonistic bacterial strains of Bacillus spp. against Alternaria alternata}

Antagonistic activity of twenty antagonistic bacterial strains of Bacillus spp (B. cereus -BSC5; B. megaterium -BmTNAU5; B. subtilis subsp. spizizenii -MM19; B. amyloliquefaciens- MM 12; B. subtilis - VB3 and B. licheniformis -B1TNAU2) against the pathogen Alternaria alternata was evaluated in vitro by standard protocol given by Matar et al. (2009) with slight modifications. Agar wells were created in four corners of the Petri plates at equal distance from the periphery using sterile cork borer. Later, $10 \mu \mathrm{l}$ of $48 \mathrm{~h}$ old, bacterial suspension (OD Value @ 600 $\mathrm{nm})$ was transferred into the wells. Then, mycelia disc (9 $\mathrm{mm}$ dia) was placed at the centre of the plate under sterile condition. Simultaneously, control plate without antagonists was also maintained. The cultures were incubated at $15^{0} \pm 2^{\circ} \mathrm{C}$ for $3-5$ days and diameter of the mycelial growth was measured. Per cent Inhibition (PI) was calculated using the formula

$$
\mathrm{PI}=\frac{\mathrm{C}-\mathrm{T}}{\mathrm{C}} \times 100
$$

Where,

$\mathrm{C}$ is the growth of test pathogen $(\mathrm{mm})$ in the absence of the antagonist.

$\mathrm{T}$ is the growth of test pathogen $(\mathrm{mm})$ in the presence of the antagonist.

\section{Extraction and detection of nonvolatile metabolites}

The effective bacterial strain (Bacillus subtilis subsp. spizizenii-MM19) was cultured in Nutrient Broth (NB) and incubated at $28^{\circ} \mathrm{C}$ for 3 days. The culture filtrates along with the bacterial cells were centrifuged at $5000 \mathrm{rpm}$ for 15 minutes at $4^{\circ} \mathrm{C}$. The bacterial cells were discarded. Then supernatant was adjusted to acidic pH 2.0 with $1 \mathrm{~N} \mathrm{HCl}$. Antifungal compounds in culture broth were extracted by adding equal volume of ethyl acetate and shaked for $2 \mathrm{~h}$ in an orbital shaker at $200 \mathrm{rpm}$. Culture broth was extracted twice with ethyl acetate for complete extraction. The solvent fraction with antifungal compounds were combined and concentrated by evaporation in the rotary flask evaporator maintained at $60^{\circ} \mathrm{C}$ at $80 \mathrm{rpm}$. The concentrated crude metabolites of the extracellular antifungal compounds obtained from the culture broth were dissolved in $1 \mathrm{ml} \mathrm{HPLC}$ grade methanol and used for GC/MS analysis (Dheepa et al., 2016). 
Evaluating the bio efficacy of Bacillus spp. against $\mathrm{Al}$ ternaria Blight under open field conditions

Field experiment was conducted using Completely Randomized Block Design during 2018 at Paruvachi, Erode to assess the efficacy of Bacillus spp. for the management of leaf blight of marigold (variety-Benz tall). The plants were sprayed with respective bacte- rial suspensions ( $1 \% \mathrm{FS}$ at $\left.10^{8} \mathrm{CFU} / \mathrm{ml}\right)$ after disease initiation at weekly intervals for four weeks. An untreated control was also maintained. All the treatments were replicated thrice. Fifty plants in each treatment were selected at random and tagged to record observations on various traits and assessed for leaf blight incidence.

\begin{tabular}{|c|c|}
\hline \multicolumn{2}{|r|}{ Treatment details } \\
\hline $\mathrm{T}_{1}$ & Foliar spray with Bacillus cereus (BSC5) (1\%)@ $10^{8} \mathrm{CFU} / \mathrm{ml}$ \\
\hline $\mathrm{T}_{2}$ & Foliar spray with B. megaterium (BmTNAU5) - (1\%) @ $10^{8} \mathrm{CFU} / \mathrm{ml}$ \\
\hline $\mathrm{T}_{3}$ & Foliar spray with $B$. subtilis subsp. spizizenii(MM19) -(1\%)@10 $10^{8} \mathrm{CFU} / \mathrm{ml}$ \\
\hline $\mathrm{T}_{4}$ & Foliar spray with B. amyloliquefaciens (MM 12) - (1\%)@ $10^{8} \mathrm{CFU} / \mathrm{ml}$ \\
\hline $\mathrm{T}_{5}$ & Foliar spray with B. subtilis (VB3) (1\%) @ $10^{8} \mathrm{CFU} / \mathrm{ml}$ \\
\hline $\mathrm{T}_{6}$ & Foliar spray with B. licheniformis (B1TNAU2) -(1\%)@ $10^{8} \mathrm{CFU} / \mathrm{ml}$ \\
\hline $\mathrm{T}_{7}$ & Foliar spray with Bacillus sp. (MM 16) - (1\%)@ $10^{8} \mathrm{CFU} / \mathrm{ml}$ \\
\hline $\mathrm{T}_{8}$ & Foliar spray with Pseudomonas flourescens (Pf1) $-(1 \%)$ at $10^{8} \mathrm{CFU} / \mathrm{ml}$ \\
\hline $\mathrm{T}_{9}$ & Control \\
\hline
\end{tabular}

\section{Statistical analysis}

Means differences of the treatment were evaluated using Duncan's Multiple Range-Test at 5\% significance (Gomez and Gomez 1984). All the data were statistically analyzed with IRRISTAT (version. 3/93, Biometrics unit, International Rice Research Institute) and interpreted.

\section{RESULTS AND DISCUSSION}

The leaf blight pathogen was isolated from 15 different infected leaf samples of different varieties and cultured on PDA. The pathogen produced greyish black to black coloured colonies and was appressed, cottony and fluffy in nature. Mycelium was septate, branched, gray-brown to olivaceous with or without zonation. The morphological observation revealed that the leaf blight was caused by two different pathogens. Some strains produced obclavate or ovate or obpyriform to ellipsoidal conidia in chain, brown to golden brown with 3-8 transverse and 1-2 longitudinal septations representing Alternaria sp. and others produced dark colored 3-4 septate conidia with third cell is curved and larger than rest of the cells indicating Curvularia sp. Dhiman and Arora (1990) reported the occurrence of leaf spot and flower blight diseases of marigold in India and it was caused by $A$. tagetica. The pathogen associated was confirmed as A. alternata by Aktar and Shamsi (2014). The fungus produced black velvety colonies and muriform conidia. Nagrale et al. (2013) studied the morphological characters of A. alternata. They reported that the fungus initially produces hyaline mycelium that turned to greybrownish, multicelled, septate and irregularly branched.

Molecular confirmation of 15 isolates corresponding to $18 \mathrm{~s}$ rRNA gene fragment amplified the genomic product of $560 \mathrm{bp}$ (Figure 1). The genomic products were sequenced and among the 15 isolates 8 isolates were found to be Alternaria spp. and the nucleotide sequences of the Alternaria strains had $94-99 \%$ similarity with the deposited strains at NCBI. The sequences were deposited in the NCBI database and were assigned with the accession numbers (Table 1). The Internal Transcribed Spacer (ITS) of rRNA gene were used for the molecular confirmation of Alternaria sp. using the universal primer pair ITS1 and ITS4 yielded an amplicon of 560 bp (Guo-yin et al., 2013).

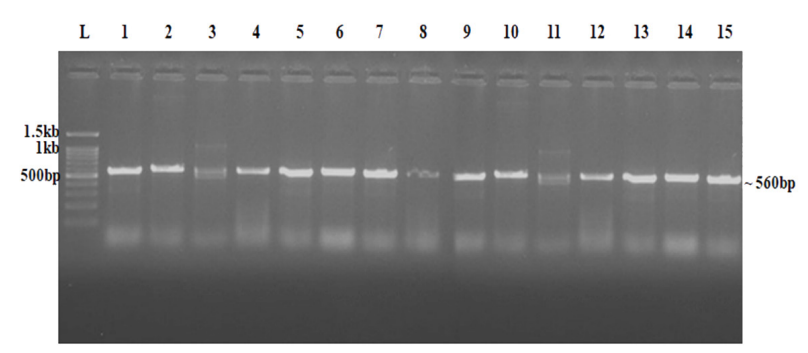

Fig. 1. PCR amplification of 18s-28sr RNA gene.

Lane L- 100bp Ladder; Lane 1- MG1; Lane 2- MG2; Lane 3- MG3; Lane 4- MG4; Lane 5- MG5; Lane 6- MG6; Lane 7- MG7; Lane 8- MG8; Lane 9- MG9; Lane 10- MG10; Lane 11- MG11; Lane 12- MG12; Lane 13MG13; Lane 14- MG14; Lane 15-MG15 
Table 1. Identification of leaf blight pathogen of marigold by partial sequencing

\begin{tabular}{|c|c|c|c|c|}
\hline S. No & $\begin{array}{l}\text { Code of sequenced } \\
\text { Isolate }\end{array}$ & Organism Identified & $\begin{array}{c}\text { Identity of sequenced } \\
\text { isolates }(\%)\end{array}$ & Acession No. \\
\hline 1 & MG1 & Alternaria sp. & 96 & MH290559 \\
\hline 2 & MG2 & Curvularia sp. & 99 & MH290510 \\
\hline 3 & MG3 & Alternaria alternata & 94 & МH290511 \\
\hline 4 & MG4 & Alternaria alternata & 98 & MH290561 \\
\hline 5 & MG5 & Alternaria alternata & 94 & MH302507 \\
\hline 6 & MG6 & Alternaria sp. & 98 & MH290564 \\
\hline 7 & MG7 & Setosperia rostrata & 99 & MH290745 \\
\hline 8 & MG8 & Curvularia sp. & 99 & MH290723 \\
\hline 9 & MG9 & Alternaria tenuissima & 90 & - \\
\hline 10 & MG10 & Alternaria tenuissima & 99 & MH290766 \\
\hline 11 & MG11 & Alternaria porri & 99 & MH291093 \\
\hline 12 & MG12 & Setosperia sp. & 99 & MH302508 \\
\hline 13 & MG13 & Curvularia papendrofii & 98 & MH292317 \\
\hline 14 & MG14 & Curvularia sp. & 99 & MH292817 \\
\hline
\end{tabular}

The leaves artificially inoculated with the conidial suspension of leaf blight pathogens Alternaria exhibited typical symptoms of leaf blight like small dark brown to black spots eight days after incubation. The pathogen was reisolated from the symptom expressed leaf and the morphological character was confirmed with the original isolates.

Among the twenty bacterial strains tested for its efficacy against Alternaria alternata through dual culture technique, fourteen strains recorded effective. The bacterial strain Bacillus subtilis subsp. Spizizenii (MM19) inhibited A. aternata to an extent of $83.99 \%$ over control and was followed by B. amyloliquefaciens strain MM12 (80.05\%) and B. subtilis VB3 (73.23\%). Among the twenty Ochrobactrum intermedium MM11 recorded the minimum inhibition of $54.56 \%$ (Table 2, Figure 2). Dragana et al., (2012) observed that Bacillus strain Q3 isolate caused a high percent of inhibition (61.75) on $A$ alternata growth. Sid et al. (2003) has documented antagonistic activity of $B$. subtilis (HS93) against $A$. alternata. Hou et al. (2006) reported that $B$. subtilis strain LEV 006 was antagonistic to four major fungal pathogens of canola including $A$. brassicae.

Table 2. In vitro efficacy of bacterial biocontrol agents in the suppression of Alternaria alternata

\begin{tabular}{|c|c|c|c|}
\hline $\begin{array}{c}\text { S. } \\
\text { No }\end{array}$ & Strains & $\begin{array}{c}\text { Mycelial } \\
\text { growth } \\
\text { (Sq.cm) }\end{array}$ & $\begin{array}{c}\text { Percent In- } \\
\text { hibition over } \\
\text { control }\end{array}$ \\
\hline 1 & $\begin{array}{c}\text { Bacillus subtilis subsp. spiz- } \\
\text { izenii (MM19) - MG645182 }\end{array}$ & 10.16 & 83.99 \\
\hline
\end{tabular}

\begin{tabular}{|c|c|c|c|}
\hline 2 & $\begin{array}{l}\text { B. amyloliquefaciens } \\
\text { (MM12) - MG645177 }\end{array}$ & 12.66 & 80.05 \\
\hline 3 & B. subtilis (VB3) - KJ603238 & 17.00 & 73.23 \\
\hline 4 & $\begin{array}{l}\text { B. megaterium (BmTNAU5) - } \\
\text { KC540825 }\end{array}$ & 17.75 & 72.05 \\
\hline 5 & B. cereus (BSC5) - JX036520 & 18.42 & 71.00 \\
\hline 6 & $\begin{array}{l}\text { Ochrobactrum ciceri(MM6) - } \\
\text { MG645171 }\end{array}$ & 19.60 & 69.16 \\
\hline 7 & $\begin{array}{l}\text { B. licheniformis (B1TNAU2) } \\
\text { - KC540818 }\end{array}$ & 22.67 & 64.30 \\
\hline 8 & O. ciceri(MM3) - MG645169 & 24.33 & 61.68 \\
\hline 9 & $\begin{array}{l}\text { B. amyloliquefaciens (VB2) - } \\
\text { KJ603230 }\end{array}$ & 26.51 & 58.24 \\
\hline 10 & $\begin{array}{l}\text { B. wiedmanni (MM15) - } \\
\text { MG645178 }\end{array}$ & 27.75 & 56.30 \\
\hline 11 & B. subtilis (BS4) - JN873300 & 32.50 & 48.82 \\
\hline 12 & $\begin{array}{l}\text { B. amyloliquefaciens (VB5) - } \\
\text { KJ603232 }\end{array}$ & 42.75 & 32.68 \\
\hline 13 & B. subtilis (VB9) - KJ603236 & 27.50 & 56.69 \\
\hline 14 & $\begin{array}{l}\text { O. intermedium (MM11) - } \\
\text { MG645175 }\end{array}$ & 28.91 & 54.46 \\
\hline 15 & $\begin{array}{l}\text { O. pseudogrignonse (MM10) } \\
\text { - MG645176 }\end{array}$ & 63.5 & 0.0 \\
\hline 16 & $\begin{array}{l}\text { Brevundimonas naejangsan- } \\
\text { ensis (MM7) - MG645173 }\end{array}$ & 63.5 & 0.0 \\
\hline 17 & $\begin{array}{l}\text { O. intermedium (MM4) - } \\
\text { MG645170 }\end{array}$ & 63.5 & 0.0 \\
\hline
\end{tabular}




\begin{tabular}{|c|l|c|c|}
\hline 18 & $\begin{array}{l}\text { O. ciceri (MM1) - } \\
\text { MG601224 }\end{array}$ & 63.5 & 0.0 \\
\hline 19 & $\begin{array}{l}\text { O. daejeonense (MM8) - } \\
\text { MG645172 }\end{array}$ & 63.5 & 0.0 \\
\hline 20 & $\begin{array}{l}\text { O. intermedium (MM13) - } \\
\text { MG645186 }\end{array}$ & 63.5 & 0.0 \\
\hline 21 & Control & 63.5 & 0.0 \\
\hline CD (0.05) & 6.04 & 8.29 \\
\hline SED & 2.99 & 4.11 \\
\hline
\end{tabular}

Data is presented as Sq. cm (mycelial growth) and percentage (Inhibition in mycelial growth over control). Error bars indicate standard error obtained from three replicates

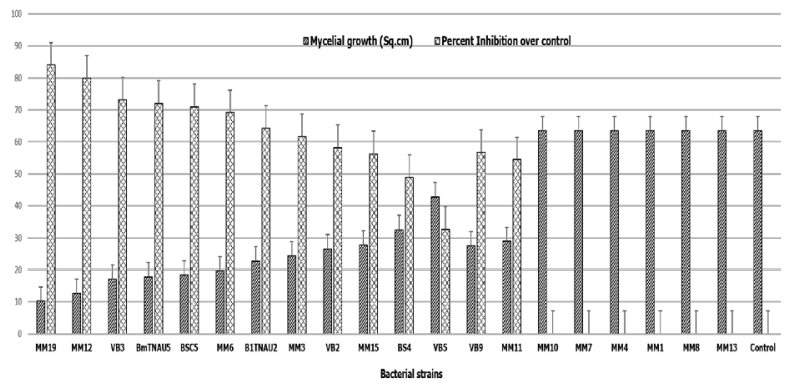

Fig. 2. Antifungal efficacy of bacterial strains against the mycelial growth of Alternaria alternata in vitro.

per treatment.

The nonvolatile compounds produced by the antagonistic bacteria Bacillus subtilis subsp. spizizenii (MM19) were Phthalic acid, isobutyl 2-pentyl ester; Dibutyl phthalate and Phthalic acid, butyl 2-pentyl ester (Figure 3 , Table 3). Phthalic acid esters are reported to possess antifungal activity (Srinivasan et al., 2009). Khatiwora et al. (2012) proved the antibacterial nature of dibutyl phthalate against Klebseilla pneumonia, Proteus mirabilis, Pseudomonas aureginosa and P. aeruginosa. The compounds Phenol, 2,4-bis(1,1-dimethylethyl)- and 1,2-Benzenedicarboxylic acid, bis(2-methylpropyl) ester possess antimicrobial nature (Santhi et al., 2013). Similarly, nonvolatile metabolites like octadecenoic acid, hexadecenoic acid, heptadecenoic acid, pyrrolo, chloroxylenol and pentadecenoic acid produced by $B$. amyloliquefaciens VB7 effectively suppressed stem rot of carnation incited by Sclerotinia sclerotiorum under protected conditions (Vinodkumar et al., 2017). Besides, Dheepa et al. (2016) demonstrated the antifungal nature of nonvolatile compounds like benzene, 1-Dodecene, Benzaldehyde, à-Dodecene, Nonadecene, Octadecanoic acid and n-Tetradec-1-ene produced by B. subtilis (BS2) against Puccinia horiana in chrysanthemum.

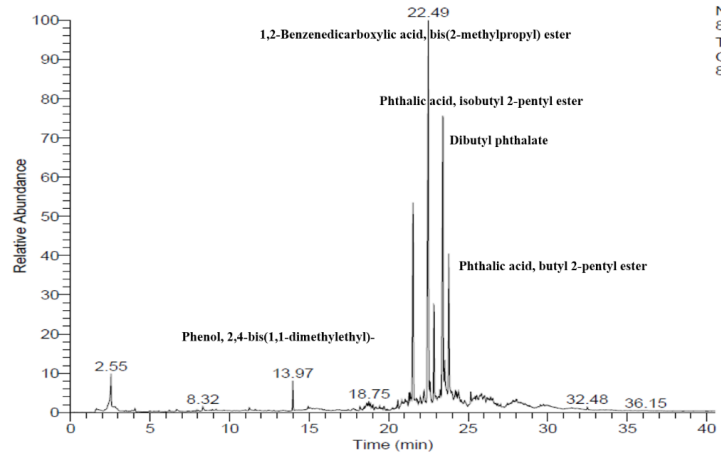

Fig. 3. Total ions chromatogram of Non volatiles compounds produced by Bacillus subtilis subsp. spizizenii (MM19).

GC/MS analysis was performed at Dept. of Nanotechnology, TNAU, Coimbatore.

Table 3. Nonvolatiles compound profile of Bacillus

subtilis subsp. spizizenii (MM19)

\begin{tabular}{|c|c|l|c|l|l|}
\hline S. No & RT & \multicolumn{1}{|c|}{ Name of the compound } & Realative Abundance & \multicolumn{1}{|c|}{ Function } & \multicolumn{1}{c|}{ Reference } \\
\hline 1 & 13.97 & $\begin{array}{l}\text { Phenol, 2,4-bis(1,1-dimethyl- } \\
\text { ethyl)- }\end{array}$ & 10 & $\begin{array}{l}\text { Antimicrobial } \\
\text { Anti inflammatory } \\
\text { Antioxidant }\end{array}$ & Santhi et al., 2013 \\
\hline 2 & 22.47 & $\begin{array}{l}\text { 1,2-Benzenedicarboxylic acid, } \\
\text { bis(2-methylpropyl) ester }\end{array}$ & 95 & Antimicrobial & Santhi et al., 2013 \\
\hline 3 & 22.85 & $\begin{array}{l}\text { Phthalic acid, isobutyl 2-pentyl } \\
\text { ester }\end{array}$ & 25 & $\begin{array}{l}\text { Antibacterial } \\
\text { Antifungal }\end{array}$ & $\begin{array}{l}\text { Srinivasan } \text { et al., } \\
2009\end{array}$ \\
\hline
\end{tabular}




\begin{tabular}{|c|c|l|c|l|l|}
\hline 4 & 23.39 & Dibutyl phthalate & 70 & Antibacterial & $\begin{array}{l}\text { Khatiwora } \text { et al., } \\
2012\end{array}$ \\
\hline 5 & 23.78 & $\begin{array}{l}\text { Phthalic acid, butyl 2-pentyl } \\
\text { ester }\end{array}$ & 35 & $\begin{array}{l}\text { Antibacterial } \\
\text { Antifungal }\end{array}$ & $\begin{array}{l}\text { Srinivasan } \text { et al., } \\
2009\end{array}$ \\
\hline
\end{tabular}

The effective six different antagonistic bacterial strains under in vitro were assessed for the management of leaf blight of marigold under field conditions. The values represent the mean of two season trails conducted during 2017 and 2018. Results indicated that, foliar spray of Bacillus subtilis subsp. spizizenii (MM19) - 1\% (10ml/L at $10^{8}$ $\mathrm{CFU} / \mathrm{ml}$ ) had the minimum leaf blight incidence of 8.15 PDI. It differed significantly from B. amyloliquefaciens (MM12) treated plants which had 11.48 PDI, followed by foliar spray with B. megaterium (BmTNAU5)-(1\%)@ 108 $\mathrm{CFU} / \mathrm{ml}$ with an incidence of 14.82 . The maximum incidence of 34.14 was observed in the plants treated with $\mathrm{Ba}$ cillus sp. (MM16). However, the mean incidence of 56.05 PDI of leaf blight was noticed in the untreated control (Figure 4, Table 4). Liuchienhui et al., (1997) reported that $B$. megaterium MBS4, B. breveis and B. subtilis var. globigii CBS10 were antagonistic to $A$. solani. Wu et al. (2007) reported the efficacy of $B$. amyloliquefaciens against $A$. cosmosa and A. patula seed borne pathogen of Cosmos sulfurous and $T$ patula. Sundaramoorthy and Balabaskar (2014) reported the antagonistic efficacy of $P$. fluorescens strains (Pf1, Py15 and Fp7) and B. Subtilis strains (EPCO 16 and EPC5) against $A$. solani. Mandhare and Suryawanshi (2003) reported that Bacillus thermophillus was found to be eaffective against $A$. porri (purple blotch of onion) and A. alternata (leaf spot of pomegranate).

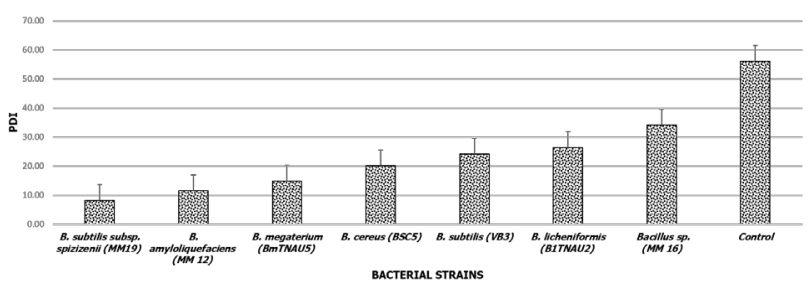

Fig. 4. Efficacy of bacterial strains on percentage leaf blight index of marigold.

The data represents mean value for two season trails conducted (2017 and 2018). Error bars indicate standard error obtained from three replicates per treatment.

Table 4. Efficacy of bacterial strains on percentage leaf blight index of marigold

\begin{tabular}{|l|l|}
\hline Treatments & PDI* $^{*}$ \\
\hline $\begin{array}{l}\text { Foliar spray with Bacillus subtilis subsp. spizizenii } \\
\text { (MM19) -(1\%)@ } 10^{8} \text { CFU/ml }\end{array}$ & 8.15 \\
\hline $\begin{array}{l}\text { Foliar spray with B. megaterium (BmTNAU5) - } \\
(1 \%) @ 10^{8} \mathrm{CFU} / \mathrm{ml}\end{array}$ & 11.48 \\
\hline
\end{tabular}

\begin{tabular}{|l|l|}
\hline $\begin{array}{l}\text { Foliar spray with B. amyloliquefaciens (MM 12) - } \\
(1 \%) @ 10^{8} \mathrm{CFU} / \mathrm{ml}\end{array}$ & 14.82 \\
\hline $\begin{array}{l}\text { Foliar spray with B. cereus (BSC5) (1\%) @ 108 } \\
\text { CFU/ml }\end{array}$ & 20.10 \\
\hline $\begin{array}{l}\text { Foliar spray with B. subtilis (VB3) (1\%) @ 108 } \\
\text { CFU/ml }\end{array}$ & 24.21 \\
\hline $\begin{array}{l}\text { Foliar spray with B. licheniformis (B1TNAU2) - } \\
(1 \%) @ 10^{8} \text { CFU/ml }\end{array}$ & 26.45 \\
\hline $\begin{array}{l}\text { Foliar spray with Bacillus sp. (MM 16) - (1\%) @ } \\
10^{8} \mathrm{CFU} / \mathrm{ml}\end{array}$ & 34.14 \\
\hline $\begin{array}{l}\text { Foliar spray with Pseudomonas flouresens (Pf1) } \\
-(1 \%) \text { at } 10^{8} \text { CFU/ml }\end{array}$ & 39.53 \\
\hline Control & 56.05 \\
\hline CD $(0.05)$ & 2.37 \\
\hline SED & 1.11 \\
\hline
\end{tabular}

Values are the pooled mean data for 2017 and $2018(P \leq 0.001)$

\section{ACKNOWLEDGEMENT}

We acknowledge Dr. V. G. Malathi and Dr. P. Renukadevi for their guidance and support. We are grateful to Professor and Head of the Department of Plant Pathology, Director (CPPS) and the Dean, (SPGS), Tamil Nadu Agricultural University for their support. We acknowledge ICAR, New Delhi for providing financial support. We would to thank DBT-FIST and UGC-SAP for creating lab facilities to carry out the research works.

\section{REFERENCE}

Aktar M, Shamsi S. 2014. Report on Alternaria blight of Tagetes erecta and Tagetes patula caused by Alternaria alternata (fr.) Keissler. J Asiatic Soc Bangladesh 40(1): 133-140.

Babu S, Seetharaman K, Nandakumar R, Johanson I. 2000. Efficacy of fungal antagonists against leaf blight of tomato caused by Alternaria solani (Ell. and Mart.) Jones and Grout. J Biol Control 14(2): 79-81.

Chakraborty BN, Chakraborty U, Saha A, Dey PL, Sunar K. 2010. Molecular characterization of Trichoderma viride and Trichoderma harzianum isolated from soils of North Bengal based on rDNA markers and analysis of their PCR-RAPD profiles. Global J Biotech Biochem. 5(1): 55-61. 
Dheepa R, Vinodkumar S, Renukadevi P, Nakkeeran S. 2016. Phenotypic and molecular characterization of chrysanthemum white rust pathogen Puccinia horiana (Henn) and the effect of liquid based formulation of Bacillus spp. for the management of chrysanthemum white rust under protected cultivation. Biol Control 103: 172-186. https://doi.org/10.1016/j.biocontrol.2016.09.006

Dhiman JS, Arora JS. 1990. Occurrence of leaf spot and flower blight of marigold (Tagetes erecta L.) in Punjab, India. J Res Punjab Agric Univ. 279(2): 231-236.

Dragana J, Katarina P, Mira S, Sasa S, Snezana P, Miladinovic M, Svetlana R. 2012. Phenazines producing Pseudomonas isolates decrease Alternaria tenuissima growth, pathogenicity and disease incidence on cardoon. Arch Biol Sci. 64 (4): 1495-1503 https://doi.org/10.2298/ABS1204495J

Gomez KA, Gomez AA. 1984. Statistical Procedure for Agricultural Research. John Wiley and Sons, New York.

Guo-yin T, Zhi-Ling Y, Zhi-lin Y, Shou-an S. 2013. Morphological, molecular and pathogenic characterization of Alternaria longipes, the fungal pathogen causing leaf spot on Atractylodes macrocephala. Afr J Microbiol Res., 7(2): 2589 - 2595.

Hou X, Boyetchko SM, Brkic M, Olson D, Ross A, Hegedus D. 2006. Characterization of the anti-fungal activity of a Bacillus spp. associated with sclerotia from Sclerotinia sclerotiorum.ApplMicrobiolBiotechnol. 72(4):644-53. https://doi.org/10.1007/s00253-006-0315-8 PMid:16496141

Karlatti RS and P. C. Hiremath. 1989. Seed borne nature of leaf and inflorescence blight in marigold and its host range. Rev Plant Pathol. 70(4): 276.

Khalil MY, Moustafa AA, Nagulb. 2007. Growth, Phenolic compounds and antioxidant activity of some medicinal plants grown under organic farming condition. World J Agric Sci. 3: 451-457.

Khatiwora E, Adsul VB, Kulkarni M, Deshpande NR, Kashalkar RV. 2012. Antibacterial activity of Dibutyl Phthalate: A secondary metabolite isolated from Ipomoea carnea stem. J Pharm Res. 5(1): 150-152.
Kolambkar RA, Suryawanshi RR, Shinde HR, Deshmukh KV. 2014. Resource productivity and resource use efficiency in marigold production. Int $J$ Com Bus Manag. 7(1): 96-99.

Liuchienhui W, Liu CH, Wu WS. 1997. Chemical and biological control of tomato early blight. Plant Pathol Bull. 6: 132-140.

Manoj Kumar S, Bhadauriab V, Singh K, Singha C, Yadav A. 2013. Screening of chilli germplasm for resistance to Alternaria leaf spot disease. Arch Phytopathol Plant Prot. 46(4): 463-469. https://doi.org/10.1080/03235408.2012.743391

Mandhare, VK, Suryawanshi, AV. 2003. Antagonistic effect of Bacillus thermophilus on some pathogens. $J$ Maharashtra Agric Univ. 28(3): 274-277.

Matar SM, El-Kazzaz SA, Wagih EE, El-Diwany AI, Moustafa HE, Abo-Zaid GA, Abd-Elsalam HE, Hafez EE. 2009. Antagonistic and inhibitory effect of Bacillus subtilis against certain plant pathogenic fungi. Biotechnology 8(1): 53-61. https://doi.org/10.3923/biotech.2009.53.61

Mishra G, Jawla S, Srivastva V. 2013. Melia azedarach: A review. Int J Med Chem Anal. 3(2): 53-56

Nagrale DT, Gaikwad AP, Sharma L. 2013. Morphological and cultural characterization of Alternaria alternata (Fr.) Keissler blight of gerbera (Gerbera jamesonii $\mathrm{H}$. Bolus ex J.D. Hook). J Appl Natural Sci. 5(1): 171-178. https://doi.org/10.31018/jans.v5i1.302

Santhi V, Sivakumar V, Mukilarasi M, Kannagi A. 2013. Antimicrobial substances of potential biomedical importance from Babylonia zeylanica. J Chem Pharm Res. 5(9): 108-115.

Shome SK and Mustafee TP. Alternaria tagetica sp. Nov. causing blight of marigold (Tagetes sp.). Curr Sci. 35: 370.

Sid A, Ezziyyani M, Egea-Gilabert C, Candela ME. 2003. Selecting bacterial strains for use in the biocontrol of diseases caused by Phytophthora capsici and Alternaria alternata in sweet pepper plants. Biol Plantarum 47(4): 569-74. https://doi.org/10.1023/ B:BIOP.0000041063.38176.4a 
Silo-Suh LA, Lethbridge BJ, Raffel SJ, He HY, Clardy J, Handelsman J. 1994. Biological activities of two fungistatic antibiotics produced by Bacillus cereus Uw85. Appl Environ Microbiol. 60: 2023-2030. PMid:8031096 PMCid:PMC201597

Simmons EG. 2007. Alternaria. An Identification Manual. CBS Biodiversity Series No. 6. CBS Fungal Biodiversity Centre, Utrecht, the Netherlands. pp. 775.

Srinivasan GV, Sharanappa P, Leela NK, Sadashiva CT, Vijayan KK. 2009. Chemical composition and antimicrobial activity of the essential oil of Leea indica (Burm. f.) Merr. flowers. Nat Prod Rad. 8(5): 488493.

Sundaramoorthy S, Balabaskar P. 2012. Consortial effect of endophytic and plant growth promoting rhizobacteria for the management of early blight of tomato incited by Alternaria solani. J Plant Pathol Microbiol. 3: 7 https://doi.org/10.4172/2157-7471.1000145

Tutte J. 1969. Plant pathological methods fungi and bacteria. Burgess publishing Company, USA. pp. 229.

Vinodkumar S, Nakkeeran S, Renukadevi P, Malathi VG. 2017. Biocontrol potentials of antimicrobial peptide producing Bacillus species: Multifaceted antagonists for the management of stem rot of carnation caused by Sclerotinia sclerotiorum. Front Microbiol. 8: 446. https://doi.org/10.3389/fmicb.2017.00446 PMid:28392780 PMCid:PMC5364326

Waghmare MB, Waghmare RM, Kamble SS. 2011. Bioefficacy of plant extracts on growth of Botrytis cinerea causing leaf blight of rose. Bioscan 6(4): 643.

White TJ, Bruns S, Lee S, Taylor J. 1990. Amplification and direct sequencing of fungal genes for phylogenetics. pp. 315-322. In: Innis MA, Gelfand DH, Sninsky JJ, White TJ (Eds.). PCR protocols: a guide to methods and applications, San Diego: Academic Press.

Wu WS, Wu HC, Li YL. 2007. Potential of Bacillus amyloliquefaciens for control of Alternaria cosmosa and A. patula of Cosmos sulfurous (Yellow Cosmos) and Tagetes patula (French Marigold). J Phytopathol. 155(11-12):670-5. https://doi.org/10.1111/j.1439-0434.2007.01293.x

Zhao Y, Tu K, Shao XF, Jing W, Yang W, Su ZP. 2008. Biological control of the post-harvest pathogens Alternaria solani, Rhizopus stolonifer and Botrytis cinerea on tomato fruit by Pichia guilliermondii. J Hort Sci Biotech. 83(1): 132- 136. https://doi.org/10.1080/14620316.2008.11512358 